\title{
Stimulasi Kemampuan Menulis Kata melalui Media Visual Berupa Gambar Pada Pelajaran Bahasa Indonesia Kelas II SD Negeri 09 Kepahiang
}

\author{
Desimah Saragih \\ SD Negeri 09 Kepahiang \\ saragih.desimah@gmail.com
}

\begin{abstract}
The lack of students' ability to compose and to write words, became the basis and background of this Classroom Action Research. All of this happens, because the teacher never used any exciting material to teach the students and in the end the lesson became boring and lack of enthusiasm from the students. This research was conducted to stimulate the ability of students to write down the words using Visual Media in the form of Images. This Classroom Action Research was conducted in 2 cycles. This research was conducted in $2^{\text {nd }}$ year of Public Primary School 09 Kepahiang, with the total of 20 students that consist of 8 male students and 12 Female Students. Data Collecting Technique that used in this research was Observation and Reflection. The collected data was analyzed using Qualitative and Quantitative analyzing technique. The result of this Classroom Action Research showed that by using Visual Media in the form of Images, the class activity became more fun and the students' learning outcome improve dramatically. Based on the results of research, a conclusion can be drawn that the use of Visual Media in the form of Images can improve students' word writing skills
\end{abstract}

Keywords: Writing Skills, Visual Media, and Images

\begin{abstract}
Abstrak
Rendahnya kemampuan siswa dalam membentuk dan menulis kata, menjadi dasar dan latar bekalang dari Penelitian Tindakan Kelas ini. Hal ini terjadi, karena guru tidak pernah menggunakan materi yang menarik saat mengajar siswa dan pada akhirnya pembelajaran menjadi membosankan dan kurangnya antusiasme dari para siswa. Penelitian ini dilakukan untuk menstimulasi kemampuan siswa dalam menulis kata menggunakan Media Visual berupa Gambar. Penelitian tindakan kelas ini dilakukan dalam 2 Siklus. Penelitian dilakukan di Kelas II SD Negeri 09 Kepahiang, dengan total 20 siswa yang terdiri dari 8 siswa laki-laki dan 12 siswa perempuan. Teknik Pengumpulan Data yang digunakan dalam penelitian ini adalah Observasi dan Refleksi. Data yang terkumpul dianalisis menggunakan teknik analisis Kualitatif dan Kuantitatif. Hasil dari Penelitian Tindakan Kelas ini menunjukkan bahwa dengan menggunakan Media Visual berupa Gambar, kegiatan pembelajaran menjadi lebih menyenangkan dan hasil belajar siswa meningkat secara dramatis. Dari hasil penelitian dapat ditarik kesimpulan bahwa dengan menggunakan Media Visual Berupa Gambar dapat meningkatkan kemampuan menulis kata siswa.
\end{abstract}

Kata Kunci: Kemampuan Menulis, Media Visual, dan Gambar 


\section{Pendahuluan}

Pembelajaran Bahasa Indonesia yang ditemukan di Sekolah Dasar (SD) khususnya di Kelas II menekankan pada kemampuan siswa agar dapat membaca dan menulis permulaan. Putra (2014) mengemukakan bahwa menulis sebagai suatu keterampilan berbahasa yang dipergunakan untuk berkomunikasi secara tidak langsung. Bahwa menulis adalah suatu kegiatan yang aktif dan produktif serta memerlukan cara berpikir yang teratur yang diungkapkan dalam bahasa tulis. Kemampuan tersebut harus dapat dikuasai siswa. Pada dasarnya siswa dikelas II sekolah dasar sudah mampu menulis, tetapi dalam kesehariannya banyak siswa yang ternyata belum mampu. Tanpa memiliki kemampuan menulis yang memadai sejak dini, anak akan mengalami kesulitan belajar pada masa selanjutnya. Puri (2015) menjelaskan kurangnya stimulus kepada siswa untuk mengukapkan ide atau gagasan dalam membentuk tulisan, menjadi salah satu faktor rendahnya kemampuan siswa dalam menulis kata.

Banyak peneliti yang sudah melakukan penelitian dengan topik kesulitan menulis pada siswa dan salah satunya adalah Zulela (2014) menemukan bahwa dari hasil pengamatan selama proses pembelajaran dan hasil tes menunjukkan bahwa kesulitan siswa dalam mengungkapkan ide secara tertulis sangat menonjol. Banyak siswa yang dapat bercerita secara lisan dengan baik, tetapi ketika diberikan tugas menuliskannya, mereka merasa sulit. Hal ini terjadi karena terbatasnya pengetahuan siswa akan struktur kalimat yang baik dan kosakata yang masih sangat terbatas. Kesulitan siswa dalam menulis juga terjadi di kelas II SD Negeri 09 Kepahiang. Berdasarkan hasil pengamatan dan wawancara dengan Guru di Kelas II SD Negeri 09 Kepahiang, Guru memberi informasi bahwa di Kelas II terdapat beberapa siswa yang kemampuan menulisnya tergolong rendah. Guru berpendapat, kemungkinan hal ini terjadi karena guru belum dapat menerapkan metode yang tepat untuk meningkatkan kemampuan menulis permulaan siswa.

Kurangnya kemampuan menulis siswa disebabkan karena kurangnya minat siswa dalam hal menulis, adanya gangguan memori sehingga siswa tidak mampu mengingat apa yang akan ditulis, dan cara siswa memegang alat pensil. Selain itu guru dalam mengajarkan cara menulis tidak menggunakan media pembelajaran yang menarik bagi siswa sehingga cenderung membosankan dan terkesan monoton. Misalnya, guru hanya memberi contoh menulis di papan tulis. Hal ini menyebabkan siswa menjadi malas dan tidak termotivasi untuk meningkatkan kemampuan menulisnya. Sebelumnya guru hanya mengajarkan prinsip-prinsip menulis tanpa mengajarkan bagaimana cara menulis yang menyenangkan sehingga siswa tertarik untuk menulis.

Salah satu instrumen yang menarik untuk digunakan sebagai bahan pembelajaran adalah Media Visual berupa Gambar. Sadiman, dkk (2011) mengungkapkan bentuk umum dari media gambar terangkum dalam pengertian media grafis. Media grafis adalah suatu media berbasis visual yang terdiri dari simbol-simbol, gambar, titik, garis untuk menggambarkan dan merangkum suatu ide dan peristiwa. Dilain pihak Sugiarti, Putra, dan Abadi (2014) mengatakan bahwa gambar adalah abstrak, tetapi mendekati kenyataan atau objek sebenarnya. Media gambar adalah suatu perantara yang paling umum dipakai. Dia merupakan bahasa yang umum, yang dapat dimengerti dan dapat dinikmati dimana-mana. Media Visual berupa Gambar adalah media yang dapat digunakan guru untuk menarik minat siswa dalam menulis khususnya menulis permulaan karena siswa dapat berimajinasi dari gambar yang diberikan oleh guru. Selain itu dengan media visual berupa gambar proses pembelajaran menjadi lebih mudah, karena siswa dapat melihat gambar tidak hanya dalam bentuk khayalan.

Adanya permasalahan dan kendala yang ditemukan guru dikelas, maka penulis memandang perlu mengadakan penelitian tindakan kelas, tujuan dilaksanakannya 
penelitian ini untuk meningkatkan kemampuan siswa kelas II SD Negeri 09 Kepahiang dalam menulis kata dengan menggunakan media visual berupa gambar.

Berdasarkan penelitian sebelumnya yang dilakukan oleh Nurnaningsih (2010) dalam skripsinya menunjukkan bahwa implementasi tindakan kelas berupa penggunaan media gambar dapat meningkatkan kemampuan membaca dan menulis. Selain itu Permana (2007) dalam skripsinya menunjukkan bahwa penggunaan media gambar seri dapat meningkatkan kemampuan siswa dalam menulis karangan. Dari kedua penelitian tersebut dapat dilihat adanya peningkatan hasil belajar yang cukup signifikan setelah dilakukannya pembelajaran menggunakan media visual berupa gambar. Penelitian yang dilakukan peneliti memiliki sedikit perbedaan dimana penggunaan media visual berupa gambar tidak hanya terbatas pada gambar-gambar statis tapi juga berupa animasi, dan instrumen semacam ini masih jarang digunakan karena kurangnya kemampuan dalam menggunakan perangkat elektronik khususnya komputer (laptop) dan projector.

\section{Metode}

Penelitian ini dilaksanakan dengan menggunakan metode Penelitian Tindakan Kelas (PTK), yaitu suatu bentuk penelitian yang bersifat reflektif dimana dengan melakukan suatu tindakan yang tepat dan terencana dengan matang dapat memperbaiki sekaligus meningkatkan mutu kegiatan belajar dan mengajar.

Ojam dan Smulyan (1989) mengungkapkan dalam prakteknya Penelitian Tindakan Kelas mempunyai 4 macam bentuk, yaitu: 1. Guru sebagai Peneliti (Teacher as Researcher), 2. Penelitian Tindakan Kolaboratif (Collaborative Action Research), 3. Penelitian Tindakan Simultan Integrasi (Simultan Integrated Action Research), 4. Administrasi Sosial Eksperimental (Experimental Social Administration).

Dalam penelitian ini, Penelitian Tindakan Kolaboratif. Dengan menggunakan bentuk ini, peneliti terlibat secara langsung sebagai peneliti dan bekerjasama dengan guru didalam kelas, serta terlibat secara penuh dalam perencanaan, tindakan, penelitian, dan refleksi.

Penelitian tindakan kelas ini menggunakan model penelitian Kemmis dan Mc.Taggart (1988). Model yang selanjutnya dikenal sebagai Sistem Spiral Refleksi ini di kembangkan dari model penelitian Kurt Lewin. Ada 4 komponen yang menjadi dasar model ini, yaitu: Planning (Perencanaan), Action (Tindakan), Observing (Penelitian) dan Reflection (Refleksi).

Subjek atau Partisipan dalam penelitian ini adalah Guru serta siswa di kelas II SD Negeri 09 Kepahiang Kecamatan Kepahiang Kabupaten Kepahiang dengan siswa di kelas tersebut yang memiliki toal 20 orang yang terdiri dari 8 siswa laki-laki dan 12 siswa perempuan. Penetapan lokasi penelitian ini didasarkan pada pertimbangan bahwa masih banyak ditemukan siswa yang mengalami kesulitan dalam menulis. Serta penelitian dengan menggunakan Media Visual berupa Gambar dalam pembelajaran menulis kata belum pernah dilakukan.

Instrumen yang digunakan dalam penelitian ini adalah, lembar observasi, soal-soal tes, gambar-gambar dalam bentuk Flash Card dan Lembar Kerja Siswa yang memuat soal-soal dengan gambar-gambar yang menarik buat siswa.

Dalam penelitian ini data bersumber dari siswa, guru, dokumen hasil kegiatan belajar dan mengajar. Teknik atau metode yang digunakan dalam pengumpulan data adalah observasi dan evaluasi, yang mana sudah menjadi rujukan bagi banyak peneliti dalam melakukan berbagai macam penelitian. 
Menurut Walgito (2004), observasi merupakan suatu penelitian yang dijalankan secara sistematis dan disengaja, diadakan dengan menggunakan alat indra (terumata sekali mata) berdasarkan kejadian-kejadian yang langsung ditangkap waktu kejadian berlangsung. Sedangkan, Zainal dan Nasution dalam Wulan (2001) menyatakan bahwa evaluasi dapat dinyatakan sebagai suatu proses pengambilan keputusan dengan menggunakan informasi yang diperoleh melalui hasil pengukuran hasil belajar, baik yang menggunakan instrumen tes maupun non tes.

Data yang sudah terkumpul kemudian dianalisis dengan menggabungkan Teknik Analisis Kualitatif dan Kuantitatif. Teknik Kualitatif menggunakan wawancara dan observasi sebagai instrumen pengumpulan data, sedangkan Teknik Kuantitatif berbentuk data mentah yang mana data akan diproses dan difilter secara cermat sehingga menjadi data yang relevan. Siyoto (2015) menekankan bahwa penelitian kualitatif berdimensi, jamak, interaktif dan suatu pertukaran pengamalaman sosial yang diintepretasikan oleh individu-individu. Sedangkan penelitian kuantitatif menurut Sukmadinata (2012) dilakukan dengan angka-angka, pengolahan statistik, strutktur, dan percobaan terkontrol.

\section{Hasil}

Pra tindakan dilaksanakan sebelum kegiatan penelitian dilakukan. Tujuannya untuk dapat menetapkan langkah-langkah pembelajaran pada saat pelaksanaan penelitian melalui proses belajar mengajar. Hal-hal yang dilakukan adalah mengadakan observasi kegiatan pembelajaran, observasi materi pembelajaran, dan mengadakan tes awal. Observasi dan tes awal menunjukkan hasil sebagai berikut:

Tabel 1.1 Hasil Tes Awal

\begin{tabular}{ccccc}
\hline \multirow{2}{*}{ NILAI } & \multirow{2}{*}{ FREKUENSI } & JUMLAH & \multicolumn{2}{c}{ KETUNTASAN } \\
\cline { 4 - 5 } & 2 & NILAI & YA & TIDAK \\
\hline 40,0 & 4 & 80,0 & & 2 \\
\hline 46,7 & 5 & 186,7 & & 5 \\
\hline 53,4 & 5 & 266,7 & & \\
\hline 60,0 & 3 & 300,0 & & \\
\hline 66,7 & 1 & 200,1 & 1 & 16 \\
\hline 73,4 & 20 & 73,4 & 4 & \\
\hline JUMLAH & & $1.106,7$ & & \\
\hline
\end{tabular}

Berdasarkan hasil pengamatan serta hasil tes awal terdapat banyak kekurangan. Dimana nilai terendah yang diperoleh adala 40,0 dan tertinggi 73,4 menghasilkan persentase observasi siswa hanya sebesar $20 \%$. Sehingga pada Siklus II nanti akan diadakan perbaikan secara signifikan.

Setelah Siklus I dilaksanakan selama satu kali pertemuan $2 \times 35$ menit, kegiatan selanjutnya adalah memberikan tes akhir, tes ini berupa tes isian dengan jumlah soal sebanyak 5 nomor. Waktu yang diberikan untuk menyelesaikan soal ini adalah $2 \times 35$ menit. Hasil observasi yang dilakukan pada aktfitas siswa, ditemukan nilai terendah 53,4 dan nilai tertinggi 86,7 menghasilkan persentase observasi siswa sebesar $45 \%$. Dengan demikian tingkat keberhasilan aktifitas siswa menurut peneliti termaksud pada kategori sangat baik. Setiap pertemuan siswa diberikan tugas mengerjakan Lembar Kerja Siswa yang digunakan sebagai tolak ukur kemampuan siswa dalam memahami materi yang diajarkan. Pada tahap Refleksi peneliti melihat kembali serta mendiskusikan hal ini dengan guru pengajar cara untuk meningkatkan hasil pemebelajaran yang siginifikan dan cara metode penggunaan Media Visual berupa Gambar yang lebih efektif. Adapun Hasil tes akhir Siklus I ditunjukkan pada tabel dibawah: 
Tabel 1.2 Hasil Tes Siklus I

\begin{tabular}{|c|c|c|c|c|}
\hline \multirow{2}{*}{ NILAI } & \multirow{2}{*}{ FREKUENSI } & \multirow{2}{*}{$\begin{array}{l}\text { JUMLAH } \\
\text { NILAI }\end{array}$} & \multicolumn{2}{|c|}{ KETUNTASAN } \\
\hline & & & YA & TIDAK \\
\hline 53,4 & 5 & 266,7 & & 5 \\
\hline 60,0 & 6 & 360,0 & & 6 \\
\hline 66,7 & 4 & 266,7 & 4 & \\
\hline 73,4 & 2 & 146,7 & 2 & \\
\hline 80,0 & 2 & 160,0 & 2 & \\
\hline 86,7 & 1 & 86,7 & 1 & \\
\hline JUMLAH & 20 & $1.106,7$ & 9 & 11 \\
\hline
\end{tabular}

Sedangkan hasil observasi pada guru saat Siklus II, terlihat adanya peningkat yang signifikan dibeberapa aspek yang diamati. Dari data hasil observasi tersebut, diperoleh jumlah skor 38 dari skor maksimal 40 serta persentase yang di capai 95\%. Hal ini menunjukan bahwa data yang didapat dari aktifitas guru pada Siklus II ini termaksud dalam kategori sangat baik. Dengan demikian, kriteria yang ditetapkan dalam penelitian ini telah tercapai.

Berdasarkan hasil analisis yang dilakukan di atas, maka dapat dinyatakan bahwa suasana kegiatan pembelajaran berjalan dengan kondusif dan tidak membosankan, di mana siswa lebih antusias dan aktif mengikuti kegiatan pembelajaran. Penggunaan Media Visual berupa Gambar sebagai media pembelajaran menulis sangat menarik minat siswa sehingga siswa menjadi lebih terampil menulis. Dari hasil yang diperoleh, maka dapat ditarik kesimpulan bahwa tindakan pembelajaran yang dilaksanakan pada Siklus II telah berhasil.

Setelah dilakukan tindakan Siklus II yang dilakukan selama satu kali pertemuan, kegiatan selanjutnya adalah memberikan tes akhir. Tes ini berupa tes isian dengan jumlah soal 5 nomor. Waktu yang diberikan untuk menyelesaikan soal ini adalah $2 \times 35$ menit. Hasil tes akhir Siklus II ditunjukkan pada tabel dibawah:

Tabel 1.3 Hasil Tes Siklus II

\begin{tabular}{ccccc}
\hline \multirow{2}{*}{ NILAI } & \multirow{2}{*}{ FREKUENSI } & \multirow{2}{*}{ JUMLAH } & \multicolumn{2}{c}{ KETUNTASAN } \\
\cline { 3 - 4 } & 2 & NILAI & YA & TIDAK \\
\hline 60,0 & 1 & 720,9 & 1 & \\
\hline 73,4 & 4 & 320,0 & 4 \\
\hline 80,0 & 5 & 433,4 & 5 \\
\hline 86,7 & 5 & 466,7 & 5 \\
\hline 93,4 & 3 & 300,0 & 3 \\
\hline 100 & 20 & $1.714,4$ & 18 & 2 \\
\hline JUMLAH & & &
\end{tabular}

Berdasarkan data tersebut di atas, diketahui bahwa nilai terendah yang diperoleh siswa adalah 60 , sedangkan nilai tertinggi yang diperoleh siswa adalah 100 . Secara individu 18 orang dari 20 orang siswa telah tuntas belajar, sedangkan secara individu 2 orang dari 20 orang siswa tidak tuntas belajar. Dari hasil tersebut sebanyak $90 \%$ siswa tuntas dalam proses pembelajaran PTK ini.

\section{Pembahasan}

Penelitian ini dilakukan di SD Negeri 09 Kepahiang. Kelas yang dipilih oleh peneliti adalah Kelas II. Yang berdasarkan testimoni dan observasi awal ditemukan kemampuan menulis kata pada siswa Kelas II masih sangat rendah. Maka dengan itu peneliti mulai melakukan dengan memasuki tahap pertama yaitu Perencanaan untuk memulai menuntaskan masalah ini. Cara yang digunakan peneliti adalah dengan menggunakan Media Visual berupa Gambar yang disesuaikan dengan RPP serta Silabus Kurikulum 2013. 
Setelah itu di tahap Tindakan, peneliti mulai dengan Tes Awal untuk mengukur kemampuan siswa dan didapatkanlah hasil yang sudah dijelaskan di bagian hasil di atas. Berdasarkan analisis hasil penelitian yang sudah ditulis diatas, diketahui bahwa ketuntasan klasikal belajar bahasa Indonesia pada materi menulis kata di kelas II SD Negeri 09 Kepahiang untuk Siklus I belum memenuhi indikator yang ditetapkan. Hal ini dikarenakan pembelajaran dengan instrumen seperti ini masih sangat asing bagi para siswa.

Pada tahap Observasi Siklus I diketahui bahwa para siswa masih belum terbiasa dengan metode serta instrumen yang digunakan, khususnya pada pengerjaan Lembar Kerja Siswa. Siswa belum terlalu memahami pertanyaan yang ada dalam Lembar Kerja Siswa. Hal ini karena dari 26 huruf, masih ada siswa yang belum terlalu menguasai huruf sehingga menjadi kendala bagi guru dalam mengajarkan siswa untuk menuliskan kata.

Kegiatan Belajar dan Mengajar yang selama ini digunakan di kelas II SD Negeri 09 Kepahiang masih condong ke metode ceramah, mengakibatkan kurangnya keterlibatan siswa secara aktif dalam pembelajaran. Hasilnya, siswa menjadi kurang mampu dalam menyelesaikan tugas-tugas karena selama ini siswa hanya menerima saja tanpa diberi kesempatan untuk dapat berperan secara aktif

Pada tahap Refleksi Siklus I ditemukan bahwa pembelajaran yang dilakukan kurang berhasil jika dilihat dari hasil belajar dan penilaian terhadap siswa. Hal ini dipengaruhi karena kurangnya kesempatan yang diberikan guru kepada siswa untuk terlibat secara langsung dalam proses pembelajaran. Maka dari itu peneliti mencoba untuk melihat kembali serta mendiskusikan hal ini dengan guru pengajar cara untuk meningkatkan hasil pemebelajaran yang siginifikan dan cara metode penggunaan Media Visual berupa Gambar yang lebih efektif.

Pada Siklus II dengan memasuki tahap Perencanaan yang sama tapi dengan sedikit perbaikan, muncul hasil yang sangat menarik pada saat tahap Tindakan dimana didapat ketuntasan belajar yang diperoleh sudah berhasil memenuhi indikator yang ditetapkan. Keberhasilan ini dikarenakan siswa diberikan kebebasan untuk dapat berperan secara aktif dalam pembelajaran. Dalam Siklus II ini juga siswa sudah dapat menguasai huruf-huruf yang diajarkan guru, siswa sudah terbiasa dalam mengerjakan tugas menggunakan Media Visual berupa Gambar sebagai media pembelajaran. Siswa lebih mudah mengingat informasi yang diperoleh dan tidak mudah dilupa.

Hasil Observasi pada Siklus I ke Siklus II, ditemukan persentase penguasaan materi menulis kata melalui penerapan Media Visual berupa Gambar meningkat secara dramatis. Peningkatan ini juga dihasilkan dari siswa yang berperan seara aktif dan pemberian tugas dan latihan ang dilakukan secara berkelanjutan. Peran guru dalam memberikan pengarahan pengarahan kepada siswa dan penerapan Media Visual berupa Gambar sangat besar bagi peningkatan penguasaan materi menulis kata.

Selama melakukan penelitian yang diawali dari Siklus I sampai dengan Siklus II memang terdapat siswa yang pemahamannya dalam menganalisa gambar dan menulis kata kurang baik, namun berkat dorongan motivasi dan bimbingan secara berkala selama melaksanakan pembelajaran serta keuletan dari siswa dalam belajar sehingga mereka dapat menyelesaikan tugas yang diberikan dengan hasil memuaskan dan sesuai dengan indikator hasil penilaian yang telah ditentukan.

Ini berarti, hasil yang signifikan dari penggunaan Media Visual berupa Gambar yang sudah dijabarkan diatas dimana ditemukan bahwa penggunaan teori ini sangat mendukung hasil penelitian dan dapat diterpakan pada pembelajaran dalam kelas. Dan ini juga sejalan dengan hasil penelitian yang diungkapkan oleh Nurhayani (2013) dalam jurnalnya menyebutkan, dari hasil penelitian tersebut dapat 
disimpulkan bahwa penggunaan media gambar untuk meningkatkan keterampilan menulis deskripsi siswa kelas II SDN Jeruk I/469 Surabaya telah berhasil.

\section{Simpulan}

Berdasarkan hasil serta pembahasan dengan menggunakan rumus-rumus yang telah ditetapkan, bisa ditarik sebuah kesimpulan bahwa kemampuan menulis kata siswa Kelas II SD Negeri 09 Kepahiang melalui Media Visual berupa Gambar dapat ditingkatkan. Hal ini dibuktikan dengan peningkatan pencapaian nilai mulai dari pra tindakan sampai pada nilai akhir Siklus II. Nilai tindakan pada Siklus I mendapat rata-rata nilai 55,3 dengan tingkat ketuntasan hanya sebesar 45\%

Ketuntasan tersebut belum mencapai indikator ketuntasan berdasarkan standar minimal dalam penelitian ini, sehingga dilanjutkan dengan Siklus II. Berdasarkan hasil perolehan pada Siklus II diketahui bahwa rata-rata nilai kemampuan menulis siswa kelas II SD Negeri 09 Kepahiang melalui Media Visual berupa Gambar, yaitu 85,7 dengan jumlah ketuntasan yaitu 18 orang tuntas dan persentase sebesar $90 \%$. Dengan demikian pernyataan hipotesis tindakan dinyatakan diterima. Selanjutnya bisa disimpulkan bahwa dengan instrumen Media Visual berupa Gambar, kemampuan menulis kata pada pelajaran Bahasa Indonesia siswa Kelas II bisa ditingkatkan secara maksimal.

\section{Saran}

Dari hasil penelitian yang telah dilaksanakan, didapat hasil bahwa dengan penggunaan Media Visual berupa Gambar dapat menstimulasi serta meningkatkan kemampuan menulis kata pada siswa Kelas II SD Negeri 09 Kepahiang. Maka dengan itu sangat disarankan: (1) Guru haruslah kreatif dan berpikir out of the box dalam merencanakan dan melaksanakan Kegiatan Belajar dan Mengajar pelaksanakan pembelajaran yang sesuai dengan materi dan serta kebutuhan siswa. Dalam materi menulis kata, penggunaan Media Visual berupa Gambar menjadi solusi serta instrumen yang tepat untuk meningkatkan kemampuan siswa dalam menulis kata; (2) Sekolah juga dapat meningkatkan mutu pembelajaran Bahasa Indonesia pada materi menulis kata dengan melakukan pengadaan media pembelajaran yang tepat; (3) Peneliti lain bisa menjadikan junal ini sebagai landasan dan bahan rujukan serta sangat diharapkan dapat memberikan temuan, ide, dan gagasan lain untuk memperkuat hasil penelitian dengan menggunakan Media Visual berupa Gambar dalam rangka meningkatkan kemampuan siswa dalam menulis kata.

\section{Referensi}

Kemmis, S. \& McTaggart, R. 1988. The Action Research Planner. Australia; Deakin University

Nurhayani, E. 2013. Penggunaan Media Gambar untuk Meningkatkan Keterampilan Menulis Deskripsi. JPGSD. Volume 01 Nomor 02. 1-9

Ojam, S. N., \& Smulyan, L. 1989. Collaborative Action Research: A Develompental Approach. Sussex: Falmer Press.

Nurnaningsih, R. 2010. Upaya Meningkatkan Kemampuan Membaca dan Menulis dengan Media Gambar pada Pelajaran Bahasa Indonesia Kelas IIb MIN Ngawen Gunung Kidul (Pendekatan Penelitian Tindakan Kelas). Skripsi. UIN Sunan Kalijaga.

Permana, M. T. 2007. Meningkatkan Kemampuan Siswa dalam Menulis Karangan Melalui Penggunaan Media Gambar Seri di Kelas V SDN Cibulan II Desa Cibulan Kecamatan Lemahsugi Kabupaten Majalengka. Skripsi. Universitas Penidikan Indonesia.

Putra, N. A. 2014. Penggunaan Media Gambar Seri untuk Meningkatkan Keterampilan Menulis Narasi pada Mata Pelajaran Bahasa Indonesia Siswa 
Kelas IV SDN Moahino Kabupaten Morowali. Jurnal Keatif Tadulako Online. Vol. 2, No. 4. 230-242

Puri, A. R. 2015. Penerapan Model Induktif Kata Bergambar untuk Meningkatkan Kemampuan Menulis Kalimat Tunggal Siswa Sekolah Dasar. Skripsi. Universitas Pendidikan Indonesia.

Sadiman, A. S., dkk. 2011. Media Pendidikan: Pengertian, Pengembangan dan Pemanfaatannya. Jakarta: Rajawali Press.

Siyoto, S. 2015. Dasar Metodologi Penelitian. Yogyakarta: Literasi Media Publisihing

Sugiarti, N. L. P. Y., Putra. I. K. A., dan Abadi. I. B. G. S. 2014. Pengaruh Model Pembelajaran TTW (Think Talk Write) Berbantuan Media Gambar Berseri terhadap Keterampilan Menulis Bahasa Indonesia Siswa Kelas V SD Gugus 1 Kecamatan Kediri Tahun Ajaran 2013/2014. E-Journal MIMBAR PGSD Universitas Pendidikan Ganesha Jurusan PGSD. Vol. 2, No. 1. 1-10

Sukmadinata, N. S. 2012. Metode Penelitian Pendidikan. Bandung: PT. Remaja Rosdakarya

Walgito, B. 2004. Pengantar Psikologi Umum. Yogyakarta: Andi Offset

Wulan, A. R. 2007. Pengertian dan Esensi Konsep Evaluasi, Asesmen, Tes, dan Pengkuran. Jurnal FPMIPA Universitas Pendidikan Indonesia. www.academia.edu/download/34534033/pengertian_asesmen.pdf

Zulela, M. S. 2014. Pendekatan Kontekstual dalam Pembelajaran Menulis di Sekolah Dasar. Mimbar Sekolah Dasar. Volume 1, Nomor 1. 83-91 